\title{
Histone H2A.J
}

National Cancer Institute

\section{Source}

National Cancer Institute. Histone H2A.J. NCI Thesaurus. Code C162821.

Histone H2A.J (129 aa, 14 kDa) is encoded by the human H2AJ gene. This protein plays a role in chromatin formation. 